\title{
Effects of Oenanthe javanica on Nitrogen Removal in Free-Water Surface Constructed Wetlands under Low-Temperature Conditions
}

\author{
Siyuan Song ${ }^{1,2,+}$, Penghe Wang ${ }^{1,3,+}{ }^{\mathbb{C}}$, Yongxia Liu ${ }^{1}$, Dehua Zhao ${ }^{1,2, *}$, Xin Leng $^{1,2}$ and \\ Shuqing An ${ }^{1,2}$ \\ 1 Institute of Wetland Ecology, School of Life Science, Nanjing University, Nanjing 210046, China; \\ xiaoyuanlisa@163.com (S.S.); wangpenghe0610222@163.com (P.W.); Lyx1901@163.com (Y.L.); \\ lengx@nju.edu.cn (X.L.); anshq@nju.edu.cn (S.A.) \\ 2 Nanjing University Ecology Research Institute of Changshu (NJUecoRICH), Changshu 215500, China \\ 3 Shanghai Investigation, Design \& Research Institute Co., Ltd. (SIDRI), Shanghai 200434, China \\ * Correspondence: dhzhao@nju.edu.cn; Tel.: +86-25-89681309 \\ + Siyuan Song and Penghe Wang are co-first authors.
}

Received: 5 March 2019; Accepted: 8 April 2019; Published: 19 April 2019

\begin{abstract}
To investigate the role and microorganism-related mechanisms of macrophytes and assess the feasibility of Oenanthe javanica (Blume) DC. in promoting nitrogen removal in free-water surface constructed wetlands (FWS-CWS) under low temperatures $\left(<10^{\circ} \mathrm{C}\right)$, pilot-scale FWS-CWS, planted with $O$. javanica, were set up and run for batch wastewater treatment in eastern China during winter. The presence of macrophytes observably improved the removal rates of ammonia nitrogen $(65 \%-71 \%)$ and total nitrogen $(41 \%-48 \%)(p<0.05)$, with a sharp increase in chemical oxygen demand concentrations (about 3-4 times). Compared to the unplanted systems, the planted systems not only exhibited higher richness and diversity of microorganisms, but also significantly higher abundances of bacteria, ammonia monooxygenase gene (amoA), nitrous oxide reductase gene (nosZ), dissimilatory cd1-containing nitrite reductase gene (nirS), and dissimilatory copper-containing nitrite reductase gene (nirK) in the substrate. Meanwhile, the analysis of the microbial community composition further revealed significant differences. The results indicate that enhanced abundances of microorganisms, and the key functional genes involved with nitrogen metabolism in the planted systems played critical roles in nitrogen removal from wastewater in FWS-CWS. Furthermore, abundant carbon release from the wetland macrophytes could potentially aid nitrogen removal in FWS-CWS during winter.
\end{abstract}

Keywords: rhizospheric microorganism; community composition; gene abundance; carbon source; $\mathrm{C} / \mathrm{N}$ ratio; nitrification-denitrification

\section{Introduction}

Free-water surface constructed wetlands (FWS-CWS) consist of basins or channels with a suitable medium, such as soil and sand, for macrophyte rooting, and typically have water depths less than $0.4 \mathrm{~m}$ and hydraulic loading rates (HLR) between 0.7 and $5.0 \mathrm{~cm} \cdot \mathrm{d}^{-1}[1,2]$. In recent years, FWS-CWS have been increasingly applied as part of an integrated wastewater treatment train and as a "stand-alone" wastewater treatment technology because of their high economy and removal efficiency $[1,3]$. Previous studies have indicated that FWS-CWS can achieve a removal efficiency of over $70 \%$ for total suspended solids, chemical oxygen demand (COD), biochemical oxygen demand (BOD), and pathogens, and of typically $40 \%-50 \%$ and $40 \%-90 \%$ for $\mathrm{N}$ and $\mathrm{P}$, respectively [2,4]. The purification processes in FWS-CWS mainly occur through complex interactions between macrophytes and the associated microorganisms in the water phase $[2,4]$. The major pathway for nitrogen removal in the FWS-CWS 
is nitrification-denitrification. During nitrification, the nitrifying bacteria oxidize ammonia under aerobic conditions, while during denitrification, nitrate is converted to free nitrogen or nitrous oxide by denitrifying bacteria in the anoxic zones [5-7].

It is generally assumed that wetland macrophytes are closely related to the abundance, activity, and diversity of the rhizospheric microorganisms in FWS-CWS $[4,5,8]$. The macrophytes provide root surface for the growth of microorganisms in the rhizosphere $[9,10]$. They also provide root exudates or plant litter as a source of carbon compounds for heterotrophic bacteria [5,8,11]. In addition, aquatic macrophytes can deliver oxygen to the rhizosphere by radial oxygen loss (ROL) [12], thus affecting the redox status of wetland sediments and the aerobic microorganisms $[2,5,13,14]$. However, some researchers have concluded that macrophytes rarely affect the microbial community composition, abundance, and specific microbial functional genes [15-18]. Furthermore, some studies have indicated a limited or even negligible influence of wetland macrophytes on the nutrient removal from wastewater in constructed wetlands (CWs) under certain conditions $[19,20]$. Previous studies have also indicated that the exact effects of macrophytes in CWs are complex and remain disputed. Therefore, further research on the detailed mechanisms, especially the microbiological mechanisms, of nutrient removal from wastewater in FWS-CWS by macrophytes is necessary to help elucidate the exact role of macrophytes in CWs. Further, the temperature is an important factor influencing the wastewater treatment in FWS-CWS. Nutrient removal from wastewater remains a challenge in North China where the average water temperature during winter is lower than $10^{\circ} \mathrm{C}$, resulting in declined biotic activity [21-23]. Hence, the selection of suitable macrophyte species to mitigate the decrease in system purification capacity during winter merits attention.

The most common species used in FWS-CWS include those from the genera Typha, Scirpus, Phragmites, Juncus, and Eleocharis $[3,24,25]$. Oenanthe javanica (Blume) DC., a native aquatic macrophyte of China, has been proposed as an ideal candidate for nitrogen removal in CWs during the low-temperature season because of its advantages, such as fast growth in wastewater, tolerance to freezing temperatures, and capacity for repeated harvest [26]. However, studies on the potential of $O$. javanica for wastewater purification in FWS-CWS are still limited. In particular, the underlying microorganism-related mechanisms influencing nitrogen removal by O. javanica roots in FWS-CWS during low-temperature seasons are poorly investigated.

In the present study, FWS-CWS planted with Oenanthe javanica (Bl.) DC. as well as other control systems, were set up and fed with effluents from a secondary wastewater treatment plant (WWTP) during the low-temperature season. The nutrient removal performances were measured and compared among the different treatment systems. Plant growth dynamics, root physiological characteristics, abundances of the key functional genes involved in the nitrogen removal process as well as the microbial abundances, diversity, and community composition in the substrate were investigated to establish the exact role and detailed mechanism of nutrient removal by macrophytes in FWS-CWS. This is the first study that systematically explains the effects of $O$. javanica on the nitrogen removal in WS-CWS under low-temperature conditions.

\section{Materials and Methods}

\subsection{Experimental Design}

To investigate the precise role of macrophytes in facilitating nitrogen removal from wastewater in FWS-CWS during winter, different wastewater purification systems were built via several fiber-reinforced plastic incubators ( $2.1 \mathrm{~m}$ in length, $1.3 \mathrm{~m}$ in width, and $0.65 \mathrm{~m}$ in height) in Huai'an, Jiangsu Province, Eastern China $\left(33.3^{\circ} \mathrm{N}, 119.0^{\circ} \mathrm{E}\right)$ on 20 November 2015. These systems were: (1) FWS-CWS planted with O. javanica and substrate sand (Tcw); (2) control systems without macrophytes but with substrate sand (Tcs) [27]; (3) control systems planted with O. javanica but without the substrate sands (Tcp); (4) control systems with blank incubators filled with wastewater only (Tck). Each system included four replicates. Cleansed sand (1-2 mm in diameter; $15 \mathrm{~cm}$ in thickness) 
was used as the substrate in Tcw and Tcs. The water level of each system was $35 \mathrm{~cm}$. Several concrete bricks wrapped in polyethylene bags were used in Tcp to maintain the same liquid height as the other two groups. Planted seedlings of O. javanica with similar size (65 $\pm 2.5 \mathrm{~cm}$ in length) were selected from a local nursery and cleaned to remove the rhizospheric soil. The initial density was 26 plants per $\mathrm{m}^{2}$ (72 plants per incubator). The secondary wastewater was obtained from a neighboring WWTP and their primary characteristics are listed in Table 1 . The experiments were performed as a batch model (i.e., wastewater was filled to a liquid height of $0.3 \mathrm{~m}$ at the beginning of each batch and then drained before the next batch). Each batch lasted 10 days (hydraulic retention time $=10$ days). At the end of each batch, the water level of each system was measured to calculate changes in the water volume. There was a total of eight batches (80 days) from 10 December 2015 to 29 February 2016 in this study. A Temperature/Light Data Logger (HOBO UA-002-08; Onset, Cape Cod, MA, USA) was used to record the water temperature. The changes in water temperature during the experiment are shown in Figure A1.

Table 1. Characteristics of the influent at the beginning of 2 nd, 4 th, 6 th, and 8 th batch (means \pm S.D., $p<0.05, n=4)$.

\begin{tabular}{ccccc}
\hline Parameter & 20 December 2015 & 19 January 2016 & 29 January 2016 & 18 February 2016 \\
\hline $\mathrm{NH}_{4}{ }^{+}-\mathrm{N}\left(\mathrm{mg} \cdot \mathrm{L}^{-1}\right)$ & $8.9 \pm 0.9$ & $10.8 \pm 0.4$ & $10.8 \pm 0.3$ & $11.6 \pm 0.5$ \\
$\mathrm{NO}_{3}{ }^{-}-\mathrm{N}\left(\mathrm{mg} \cdot \mathrm{L}^{-1}\right)$ & $10.5 \pm 0.8$ & $10.8 \pm 0.7$ & $10.8 \pm 0.9$ & $10.4 \pm 0.4$ \\
$\mathrm{NO}_{2}{ }^{-}-\mathrm{N}\left(\mathrm{mg} \cdot \mathrm{L}^{-1}\right)$ & $0.650 \pm 0.025$ & $0.560 \pm 0.025$ & $0.380 \pm 0.005$ & $0.335 \pm 0.005$ \\
$\mathrm{TN}\left(\mathrm{mg} \cdot \mathrm{L}^{-1}\right)$ & $24.8 \pm 1.5$ & $25.7 \pm 3.0$ & $25.3 \pm 0.9$ & $26.6 \pm 2.0$ \\
$\mathrm{COD}\left(\mathrm{mg} \cdot \mathrm{L}^{-1}\right)$ & $14.4 \pm 2.2$ & $15.4 \pm 2.5$ & $14.6 \pm 2.8$ & $15.8 \pm 1.8$ \\
$\mathrm{DO}\left(\mathrm{mg} \cdot \mathrm{L}^{-1}\right)$ & $9.7 \pm 0.8$ & $8.9 \pm 0.5$ & $9.3 \pm 0.9$ & $8.3 \pm 0.6$ \\
$\mathrm{pH}$ & $7.88 \pm 0.65$ & $7.05 \pm 0.45$ & $6.45 \pm 0.98$ & $8.45 \pm 1.24$ \\
\hline
\end{tabular}

$\mathrm{NH}_{4}{ }^{+}-\mathrm{N}$ : ammonia nitrogen; $\mathrm{NO}_{3}{ }^{-}-\mathrm{N}$ : nitrate nitrogen; $\mathrm{NO}_{2}{ }^{-}-\mathrm{N}$ : nitrite nitrogen; $\mathrm{TN}$ : total nitrogen; $\mathrm{COD}$ : chemical oxygen demand; DO: dissolved oxygen.

\subsection{Water and Plant Sampling and Analysis}

The water in each system was sampled for water quality at the end of the 2nd, 4th, 6th, and 8th batches. The water temperature, $\mathrm{pH}$, and dissolved oxygen (DO) were measured by a Temperature/Light Data Logger (HOBO UA-002-08; Onset, Cape Cod, MA, USA), a portable Multi-parameter Water Quality Meter (U52; Horiba Ltd., Kyoto, Japan) and a DO electrode (HQ40D-53LED; Hach Company, Loveland, $\mathrm{CO}, \mathrm{USA}$ ), respectively. $\mathrm{NH}_{4}{ }^{+}-\mathrm{N}, \mathrm{NO}_{2}{ }^{-}-\mathrm{N}, \mathrm{NO}_{3}{ }^{-}-\mathrm{N}$, total nitrogen (TN), and COD were determined through water quality analyzing systems (DRB200 and DR2800; Hach Company, Loveland, CO, USA) according to standard analytical procedures [28]. The water sampling was conducted according to guidelines on sampling from lakes, natural and man-made (ISO/FDIS 5667-4:2016).

Biomass and nitrogen content of plant samples from the beginning and end of the experiment were determined according to [29]. Briefly, plant samples were separated into roots, stems, and leaves, dried at $65{ }^{\circ} \mathrm{C}$ to a constant weight, grounded into powder, and then measured by an elemental analyzer (CHN-O-Rapid; W. C. Heraeus GmbH., Hanau, Germany) [30]. Root vitality was quantified with the triphenyl tetrazolium chloride (TTC) method [29]. The rate of root ROL was measured through the titanium (III) citrate buffer method [31,32].

\subsection{Microorganism Sampling and Analysis}

\subsubsection{Preparation of Microbial Samples}

The microbial samples from the rhizoplane of wetland macrophytes and the substrates were obtained on 10 January 2016. For the rhizoplane samples, $5 \mathrm{~g}$ of root was obtained from five plants in each system and placed into clean phosphate buffer in a Falcon tube. After ultrasonic processing at $90 \mathrm{~W}$ for $30 \mathrm{~min}$, the isolated biofilm from the rhizoplane was collected by vacuum filtration with $0.22 \mu \mathrm{m}$ membranes [33]. For substrate samples, $100 \mathrm{~g}$ of sand was obtained using a cylindrical sampler (diameter, $0.5 \mathrm{~cm}$ ) from five sampling points in each system and added to a sterile glass bottle, then mixed well, and vigorously shaken at $200 \mathrm{rpm}$ for $3 \mathrm{~h}$ to isolate the biofilm. After the centrifugation 
process of samples at $5000 \times \mathrm{g}$ for $12 \mathrm{~min}$, the precipitate was collected for analysis [34]. Biofilm isolated from the rhizoplane and the substrate were used for subsequent DNA extraction, qPCR, 16S rRNA gene PCR amplification, and Illumina MiSeq sequencing.

\subsubsection{Extraction of Total Genomic DNA}

The total genomic DNA from microbial samples was first extracted and purified using QIAamp Fast DNA Stool Mini Kit (QIAGEN, Chatsworth, CA, USA) and the yield was evaluated with SpectraMax 190 (Molecular Devices, Sunnyvale, CA, USA). Subsequently, the integrity was detected with $1 \%$ agarose gel electrophoresis and stored at $-20^{\circ} \mathrm{C}$ until further use.

\subsubsection{Real-Time Quantitative PCR Analysis}

Quantitative PCR analysis of seven target functional gene fragments, (i.e., bacteria (bacterial $16 \mathrm{~S}$ rRNA gene), archaea (archaeal 16S rRNA gene), anaerobic ammonia oxidation (anammox), bacteria (ANO 16S rRNA gene), ammonia monooxygenase gene (amoA), nitrous oxide reductase gene (nosZ), dissimilatory cd1-containing nitrite reductase gene (nirS), and dissimilatory copper-containing nitrite reductase gene (nirK) was conducted using the Illumina-Eco real-time PCR system (Illumina, San Diego, CA, USA). The primers were synthesized by Genergy Biotechnology Limited Corporation (Shanghai, China) and the details are listed in Table A1. Further information regarding the qPCR analysis is shown in Table A2.

\subsubsection{S rRNA Gene Illumina MiSeq Sequencing}

PCR amplification of the $16 \mathrm{~S}$ rRNA gene was performed with the universal primer set at $341 \mathrm{~F}$ (5'-CCTAYGGGRBGCASCAG-3') and 785R (5'-GACTACHVGGGTATCTAATCC-3'). Raw fastq files were demultiplexed, quality-filtered, and merged by FASTX-Toolkit (version 0.0.14) and Mothur program (version 1.34.0,) [35]. All reads were quality filtered using an average quality value of 20 (Q20) during demultiplexing. Short reads (length $<40 \mathrm{bp}$ ) and chimeras were excluded. Reads were clustered according to the degree of similarity by using the Uclust program (version 1.2.22q, Edgar 2010). Sequences with $\geq 97 \%$ similarity were assigned to the same genus. Taxonomic information was annotated by the Ribosomal Database Project (RDP) classifier (version 2.2) [36], and the alpha diversity was analyzed by Mothur. Chao1 and Simpson index were used to estimate the species richness [37] and species diversity [38,39], respectively. More information of the 16S rRNA gene Illumina MiSeq sequencing is listed in Table A2.

\subsubsection{Sequence Storage Information}

The Illumina sequencing raw data have been deposited in the National Center for Biotechnology Information (NCBI) Sequence Read Archive database (Study Accession: SRP105263; Sample Accessions: SRS2149921, SRS2149998, SRS2149999, SRS2150553).

\subsection{Statistical Analysis}

Statistical Package for Social Sciences (SPSS) 17.0 (SPSS Inc., Armonk, NY, USA) was used for statistical analysis. The data were analyzed using a one-way analysis of variance to compare the performance of each mesocosm, and statistically significant differences $(p>0.05)$ between the mean values of the treatments were determined using Duncan's test. Nonparametric tests were used for non-normal distribution data.

\section{Results}

\subsection{Nutrient Removal Performance}

The performance of nutrient removal varied greatly across the different systems (Figure 1). Tcw and Tcp, followed by Tcs $(28.62 \%)$, achieved the highest average removal rate of $\mathrm{NH}_{4}{ }^{+}-\mathrm{N}(64.58 \%-70.68 \%)$. 
However, no significant differences in the average removal rates of $\mathrm{NO}_{3}{ }^{-}-\mathrm{N}$ and $\mathrm{NO}_{2}{ }^{-}-\mathrm{N}$ were observed among the three systems in the four detected batches. The best removal efficiency with regard to TN was observed in Tcp $(40.57 \%-46.41 \%)$ in the 2 nd, 4 th, and 6 th batches and in Tcw $(48.37 \%)$ in the 8th batch. Additionally, over time, an increase in the effluent COD concentrations was observed in Tcw and Tcp. It increased from $9.2 \mathrm{mg} \cdot \mathrm{L}^{-1}$ to $26.9 \mathrm{mg} \cdot \mathrm{L}^{-1}$ and from $9.1 \mathrm{mg} \cdot \mathrm{L}^{-1}$ to $38.2 \mathrm{mg} \cdot \mathrm{L}^{-1}$ in Tcw and Tcp, respectively. Accordingly, the ratio of COD/N in the effluent sharply increased from 0.5 to 2.1 and from 0.7 to 2.5 in Tcw and Tcp, respectively.
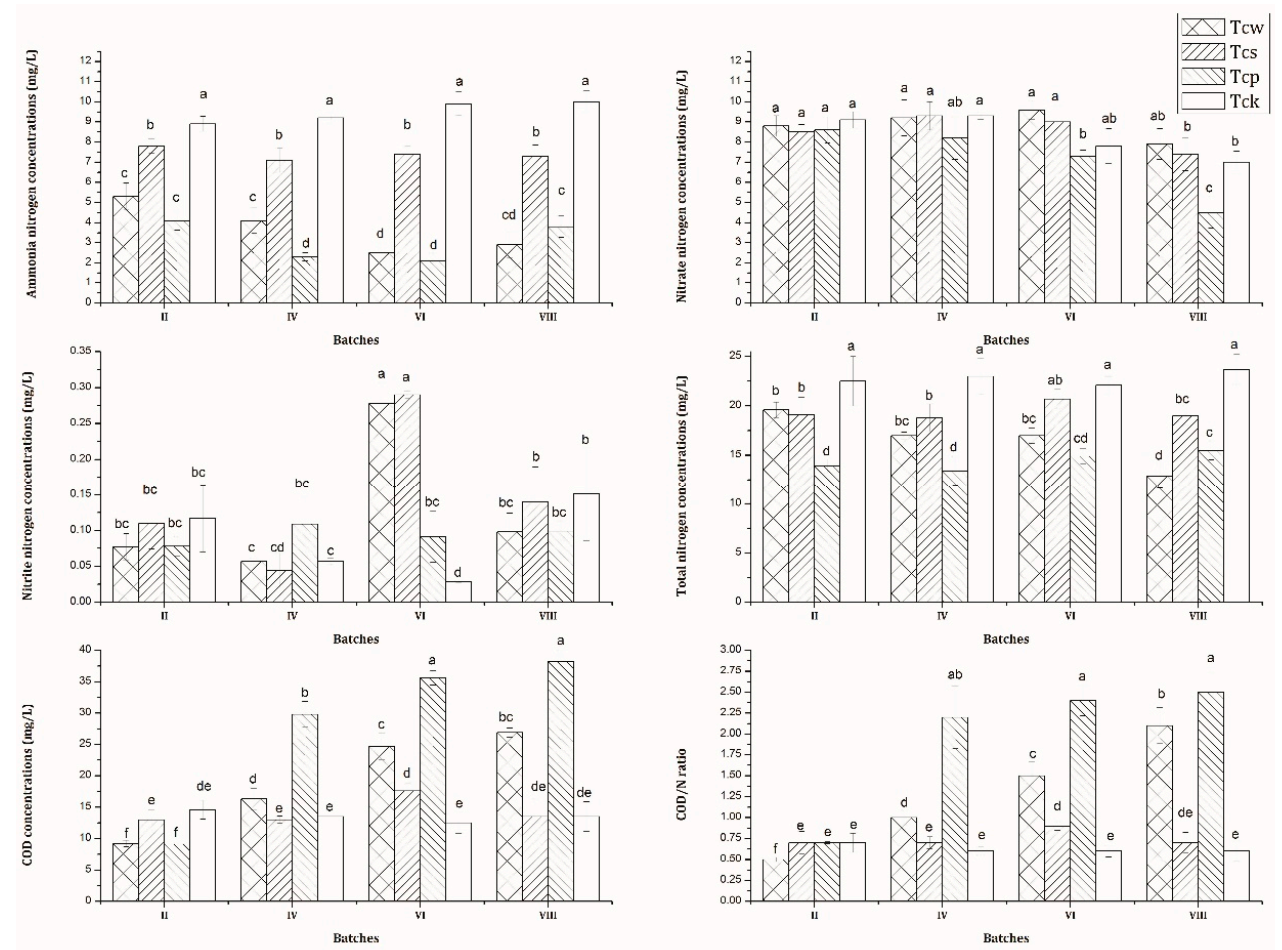

Figure 1. Concentrations (mg. $\mathrm{L}^{-1}$ ) of $\mathrm{NH}_{4}{ }^{+}-\mathrm{N}, \mathrm{NO}_{3}{ }^{-}-\mathrm{N}, \mathrm{NO}_{2}{ }^{-}-\mathrm{N}, \mathrm{TN}$, and COD as well as the $\mathrm{COD} / \mathrm{N}$ ratio $(n=4)$ Different letters indicate significant differences $(p<0.05)$ among the different systems. Tcw: free-water surface constructed wetlands (FWS-CWS) planted with O. javanica in substrate; Tcs: control systems without plants; Tcp: control systems without sands; Tck: control systems with blank incubators filled with wastewater only. II, IV, VI, and VIII represent respectively the 2nd, 4th, 6th, and 8th batch of different systems (Tcw, Tcs, Tcp, and Tck).

\subsection{Plant Growth Dynamics and Physiological Root Characteristics}

Table 2 shows the plant lengths, biomass, nitrogen content, and root activity as well as the ROL rate. The data indicate slight plant growth during the operation; however, no obvious difference was observed among these indicators between Tcw and Tcp. First, the plant shoot lengthened by $5.0-6.0 \mathrm{~cm}$ while the plant root lengthened by $7.6-8.0 \mathrm{~cm}$ at the end of the 8th batch in Tcw and Tcp. Meanwhile, the plant shoot biomass was enhanced by $7.3-9.5 \mathrm{~g} \cdot \mathrm{m}^{-2}$ while the plant root biomass was enhanced by $11.8-13.0 \mathrm{~g} \cdot \mathrm{m}^{-2}$ during the operation period. Accordingly, the nitrogen content also increased by $0.110-0.143 \mathrm{~g} \cdot \mathrm{m}^{-2}$ and $0.108-0.117 \mathrm{~g} \cdot \mathrm{m}^{-2}$ in the shoot and root, respectively. Unlike the plant growth dynamics indicators, the physiological characteristics of plant root presented a mild fluctuation in Tcw and Tcp during the operation period. The plant root vitality showed a slight decline at the end of 2nd, 4th, and 6th batches in comparison to the beginning, but increased to 58.7-63.6 $\mu \mathrm{g} \mathrm{TTC} \cdot \mathrm{g}^{-1} \mathrm{root} \cdot \mathrm{h}^{-1}$ at the end of the 8th batch. Further, the ROL rates increased by $0.32-0.52 \mu \mathrm{mol} \mathrm{O}_{2} \cdot \mathrm{g}^{-1} \mathrm{root} \cdot \mathrm{h}^{-1} \mathrm{in} \mathrm{Tcw}$ and Tcp at the end of 8th batch, though they presented a slight decline at the end of the 2nd and 4th batches when compared to the beginning. 
Table 2. Length, biomass, nitrogen content, root activity, and radial oxygen loss (ROL) rate in the plants (means \pm SD., $p<0.05, n=4$ ).

\begin{tabular}{|c|c|c|c|c|c|c|c|c|c|}
\hline Phase & System & $\begin{array}{l}\text { Shoot Length } \\
\text { (cm) }\end{array}$ & $\begin{array}{l}\text { Root Length } \\
\text { (cm) }\end{array}$ & $\begin{array}{l}\text { Shoot Biomass } \\
\quad\left(\mathrm{g} \cdot \mathrm{m}^{-2}\right)\end{array}$ & $\begin{array}{l}\text { Root Biomass } \\
\quad\left(\mathrm{g} \cdot \mathrm{m}^{-2}\right)\end{array}$ & $\begin{array}{c}\mathrm{N} \text { in Shoot } \\
\left(\mathrm{g} \cdot \mathrm{m}^{-2}\right)\end{array}$ & $\begin{array}{l}\mathrm{N} \text { in Root } \\
\left(\mathrm{g} \cdot \mathrm{m}^{-2}\right)\end{array}$ & $\begin{array}{c}\text { Root Activity } \\
\left(\mu \mathrm{g} \text { TTC } \cdot \mathrm{g}^{-1}\right. \\
\left.\operatorname{Root}^{-1} \mathrm{~h}^{-1}\right)\end{array}$ & $\begin{array}{c}\text { ROL Rate } \\
\left(\mu \mathrm{mol} \mathrm{O} \cdot \mathrm{g}^{-1}\right. \\
\left.\text { Root } \cdot h^{-1}\right)\end{array}$ \\
\hline \multirow{2}{*}{ Initial } & Tcw & $50.0 \pm 2.5$ & $15.0 \pm 1.0$ & $95.0 \pm 6.3$ & $35.0 \pm 3.6$ & 1.425 & 0.315 & $48.5 \pm 6.4$ & $0.96 \pm 0.045$ \\
\hline & Tcp & $50.0 \pm 2.5$ & $15.0 \pm 1.0$ & $95.0 \pm 6.3$ & $35.0 \pm 3.6$ & 1.425 & 0.315 & $48.5 \pm 6.4$ & $0.96 \pm 0.045$ \\
\hline \multirow{2}{*}{ 2nd Batch } & Tcw & $52.0 \pm 2.7$ & $16.0 \pm 1.4$ & $86.0 \pm 5.3$ & $35.8 \pm 5.5$ & 1.290 & 0.322 & $42.6 \pm 3.7$ & $0.68 \pm 0.097$ \\
\hline & Tcp & $52.0 \pm 2.8$ & $16.0 \pm 1.3$ & $84.0 \pm 6.5$ & $36.4 \pm 3.7$ & 1.260 & 0.328 & $46.7 \pm 5.2$ & $0.88 \pm 0.098$ \\
\hline \multirow{2}{*}{ 4th Batch } & Tcw & $55.0 \pm 3.5$ & $17.0 \pm 1.5$ & $87.0 \pm 5.8$ & $37.0 \pm 4.1$ & 1.305 & 0.333 & $43.2 \pm 5.3$ & $0.79 \pm 0.054$ \\
\hline & $\mathrm{Tcp}$ & $55.0 \pm 3.4$ & $17.7 \pm 1.2$ & $87.2 \pm 7.6$ & $38.3 \pm 3.3$ & 1.305 & 0.345 & $46.4 \pm 5.5$ & $0.87 \pm 0.093$ \\
\hline \multirow{2}{*}{ 6th Batch } & Tcw & $54.0 \pm 2.6$ & $20.5 \pm 2.0$ & $92.3 \pm 5.7$ & $40.5 \pm 5.2$ & 1.385 & 0.365 & $42.8 \pm 4.5$ & $1.02 \pm 0.065$ \\
\hline & $\mathrm{Tcp}$ & $53.0 \pm 1.7$ & $20.0 \pm 2.4$ & $91.6 \pm 6.5$ & $40.6 \pm 5.1$ & 1.374 & 0.365 & $47.5 \pm 6.2$ & $1.03 \pm 0.061$ \\
\hline \multirow{2}{*}{ 8th Batch } & Tcw & $56.0 \pm 2.5$ & $22.6 \pm 2.2$ & $102.3 \pm 13.5$ & $46.8 \pm 4.3$ & 1.535 & 0.421 & $58.7 \pm 6.5$ & $1.28 \pm 0.078$ \\
\hline & $\mathrm{Tcp}$ & $55.0 \pm 2.5$ & $23.0 \pm 2.7$ & $104.5 \pm 14.4$ & $48.0 \pm 4.8$ & 1.568 & 0.432 & $63.6 \pm 8.9$ & $1.48 \pm 0.085$ \\
\hline
\end{tabular}

Tcw: FWS-CWS planted with O. javanica in substrate; Tcp: control systems without sands. The plant in each system was sampled at the initial time of the experiment and at the end of the

2nd, 4th, 6th, and 8 th batches. 


\subsection{Microbial Population and Composition}

The absolute abundances of bacteria, archaea, and anammox as well as the four functional genes, (i.e., amoA, nosZ, nirS, and nirK) in the samples from plant roots or sand in the three systems are shown in Figure 2. Except for anammox and nirK, the abundances of bacteria, archaea, amoA, nosZ, and nirS in samples from rhizoplane in Tcw (Ps) were higher when compared to samples from rhizoplane in Tcp (Pw). The copy numbers in Ps were recorded as $8.947 \times 10^{10}$ copies. $\mathrm{g}^{-1}$ root (bacteria), $1.954 \times 10^{11}$ copies. ${ }^{-1}$ root (archaea), $7.335 \times 10^{7}$ copies $\cdot \mathrm{g}^{-1} \operatorname{root}(a m o A), 1.491 \times 10^{7}$ copies $\cdot \mathrm{g}^{-1}$ root (nosZ), and $2.517 \times 10^{8}$ copies. $\mathrm{g}^{-1}$ root (nirS), while the numbers were $7.017 \times 10^{10}$ copies. $\mathrm{g}^{-1}$ root (bacteria), $7.871 \times 10^{10}$ copies $\cdot \mathrm{g}^{-1} \operatorname{root}(\operatorname{archaea}), 4.828 \times 10^{7}$ copies $\cdot \mathrm{g}^{-1} \operatorname{root}(a m o A), 6.812 \times 10^{6} \mathrm{copies}^{-\mathrm{g}^{-1}}$ $\operatorname{root}\left(\right.$ nosZ), and $2.017 \times 10^{8}$ copies. $\mathrm{g}^{-1} \operatorname{root}($ nirS $)$ in Pw. On the other hand, significantly high abundances of all seven target functional gene fragments were observed in samples from sand in Tcw (Sp) when compared to samples from sand in Tcs (Su). The copy numbers of bacterial 16S rRNA, archaeal 16S rRNA, anammox bacterial $16 \mathrm{~S}$ rRNA, amoA, nosZ, nirS, and nirK in Sp were recorded as $7.987 \times 10^{8}$ copies.g ${ }^{-1}$ sand, $1.049 \times 10^{10}$ copies. $\mathrm{g}^{-1}$ sand, $2.392 \times 10^{7}$ copies $\cdot \mathrm{g}^{-1}$ sand, $5.413 \times 10^{7}$ copies $\cdot \mathrm{g}^{-1}$ sand, $1.716 \times 10^{6}$ copies $\cdot \mathrm{g}^{-1}$ sand, $2.842 \times 10^{7}$ copies $\cdot \mathrm{g}^{-1}$ sand, and $7.865 \times 10^{6}$ copies $\cdot \mathrm{g}^{-1}$ sand, respectively, while they were $3.220 \times 10^{8}$ copies $\cdot \mathrm{g}^{-1}$ sand, $7.930 \times 10^{9}$ copies $\cdot \mathrm{g}^{-1}$ sand, $1.241 \times 10^{7}$ copies $\cdot \mathrm{g}^{-1}$ sand, $3.658 \times 10^{7}$ copies. ${ }^{-1}$ sand, $3.897 \times 10^{5}$ copies $\cdot \mathrm{g}^{-1}$ sand, $2.170 \times 10^{7}$ copies $\cdot \mathrm{g}^{-1}$ sand, and $4.343 \times 10^{6}$ copies $\cdot \mathrm{g}^{-1}$ sand, respectively, in Su.
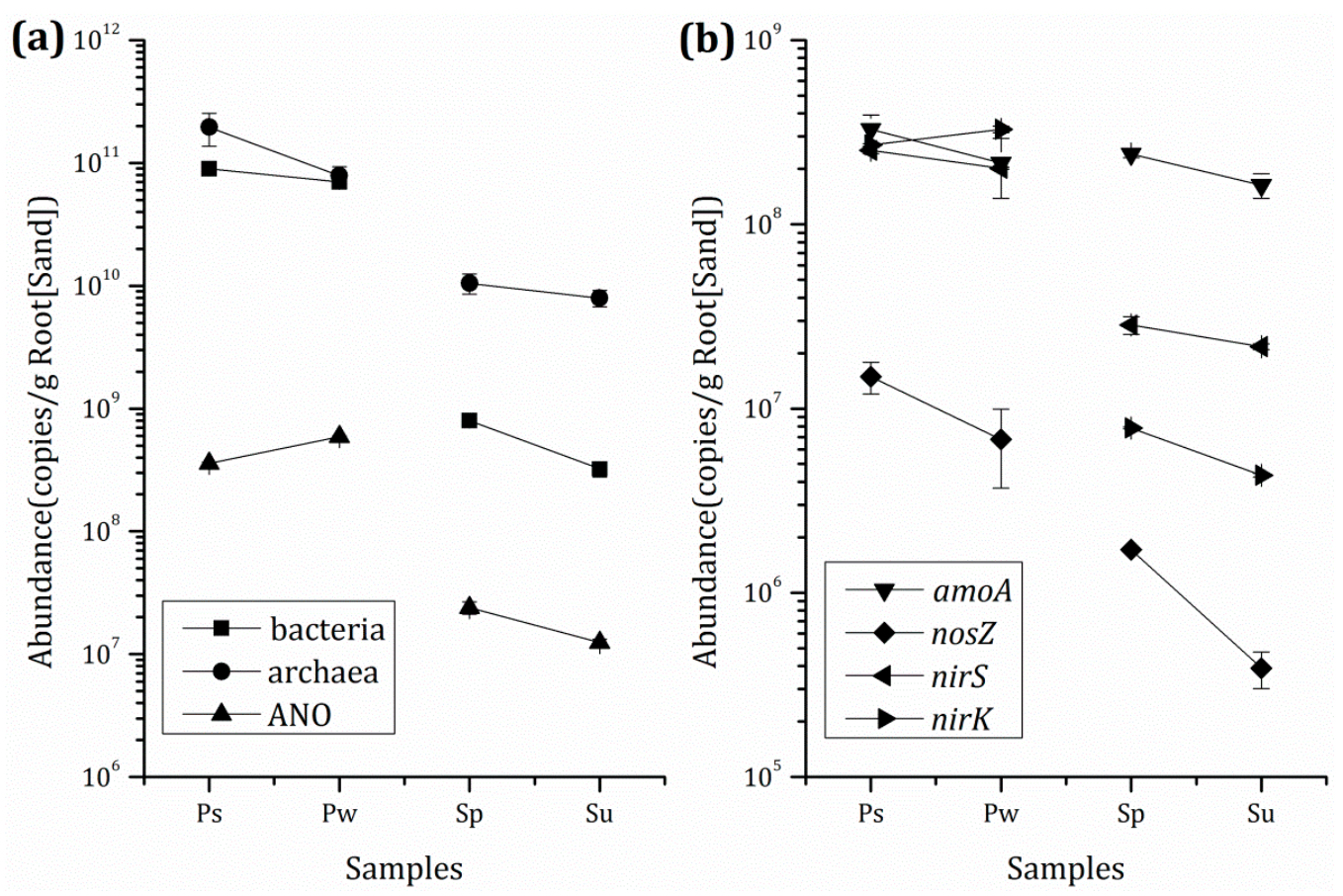

Figure 2. Absolute abundances of microbial communities and functional genes: (a) bacterial 16S rRNA, archaeal 16S rRNA, and 16S rRNA related to anammox bacteria; (b) amoA, nosZ, nirS, and nirK $(n=3)$. Ps: sample from rhizoplane in Tcw; Pw: sample from rhizoplane in Tcp; Sp: sample from sand in Tcw; Su: sample from sand in Tcs. The microbial samples from the plants rhizoplane and the substrate were obtained in the end of the 6th batch.

Alpha diversity analysis based on the 16S rRNA gene MiSeq sequencing shows the community composition characteristics of microorganisms from plant rhizosphere and sand in the three systems (Table A3). The community richness was analyzed by calculating the Chao1 estimator at $5 \%$ dissimilarity, while community diversity was estimated by Shannon index at $5 \%$ dissimilarity. Community evenness was indicated via Shannon-even index at $5 \%$ dissimilarity. The results showed a significant improvement in richness, diversity, and evenness of microbial communities in the plant roots of $\mathrm{Pw}$ in contrast to 
those of Ps. Meanwhile, an obvious superiority of microbial community diversity and evenness was observed for $\mathrm{Sp}$ in comparison to Su.

A pairwise comparison of the bacterial community composition at the phylum level is shown in Figure 3. A total of 25 distinguishable phyla were detected, of which $0.06 \%, 0.21 \%, 1.41 \%$, and $0.80 \%$ were unclassified reads in Ps, Pw, Sp, and Su, respectively. In Ps and Pw, the dominant phylum Proteobacteria accounted for $84.29 \%$ of the total reads, followed by Firmicutes with relative abundances of $11.28 \%$ (Ps) and $8.80 \%(\mathrm{Pw})$, followed by Bacteroidetes, of which, the relative abundances were recorded as $2.19 \%(\mathrm{Ps})$ and $2.56 \%(\mathrm{Pw})$. A different phylum abundance order was found in bacterial samples from Sp and Su. Though the dominant phylum was also Proteobacteria (70.08\% for Sp, 78.49\% for $\mathrm{Su}$ ), the second abundant phylum was Bacteroidetes (15.20\% for Sp, 10.26\% for Su), followed by Actinobacteria (3.36\%) in Sp and Firmicutes (2.93\%) in Su.

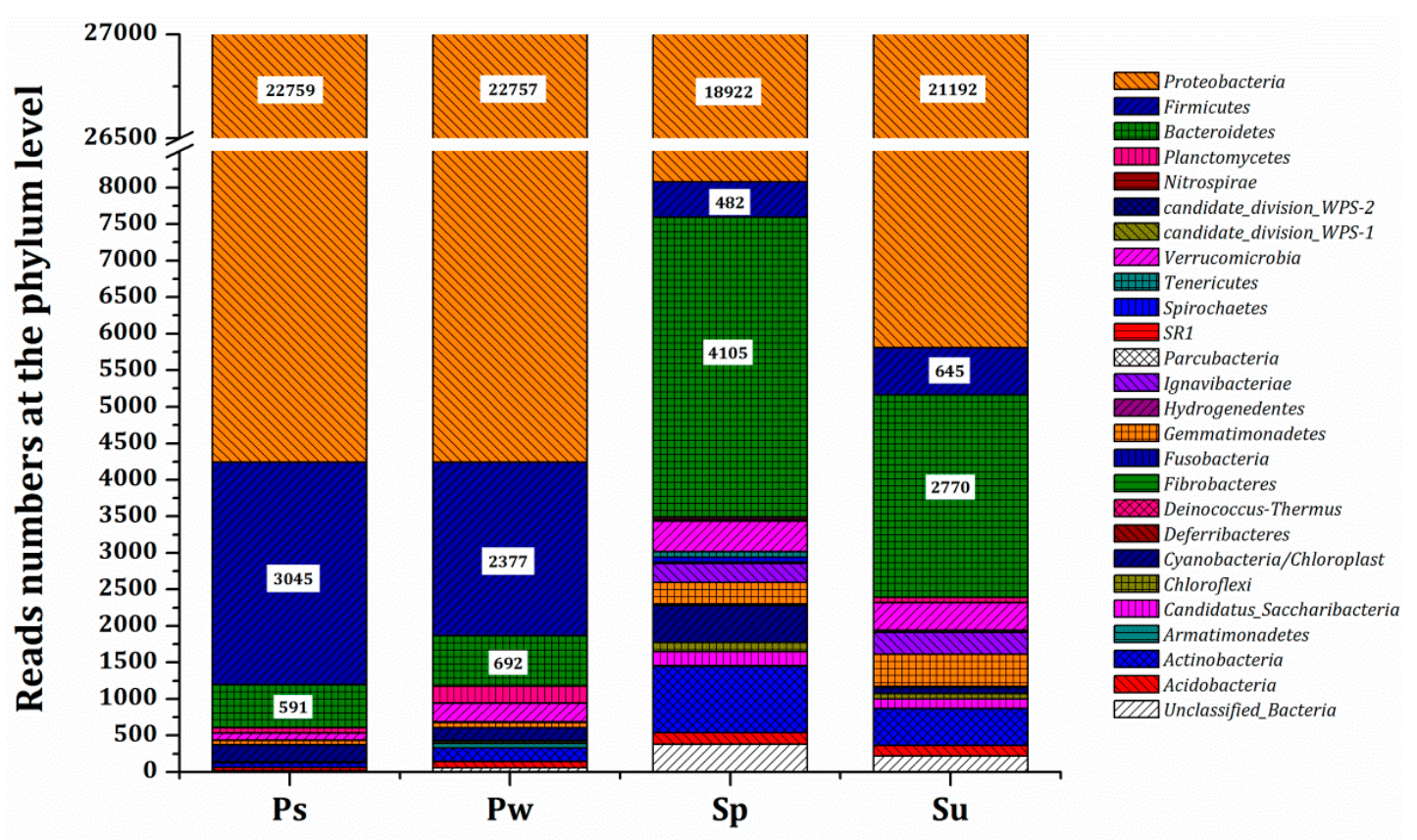

Four microbial samples from plants or sands

Figure 3. Microbial communities in the samples from plants or sands at the phylum level. Some phyla (read numbers <10) are grouped into "others". Ps: sample from rhizoplane in Tcw; Pw: sample from rhizoplane in Tcp; Sp: sample from sand in Tcw; Su: sample from sand in Tcs. The microbial samples from the plants rhizoplane and the substrate were obtained at the end of the 6th batch.

Furthermore, the predominant phylum Proteobacteria was extensively analyzed by order (Figure 4). The samples from Ps and Pw shared a similar composition of order, and differences were observed only in the relative abundances of the primary orders. These were recorded as Pseudomonadales $(74.70 \%)$, Aeromonadales $(2.44 \%)$, Burkholderiales $(1.79 \%)$, and Rhizobiales $(1.12 \%)$ in Ps, and Pseudomonadales (66.15\%), Aeromonadales (7.23\%), Burkholderiales $(2.37 \%)$, and Rhizobiales (2.09\%) in Pw. The microbial samples presented larger differences between $\mathrm{Sp}$ and $\mathrm{Su}$ with regard to order composition. The predominant orders in Sp included Oceanospirillales (14.49\%), Burkholderiales (14.33\%), Pseudomonadales $(8.80 \%)$, Xanthomonadales (6.49\%), Sphingomonadales (4.76\%), Rhodobacterales (4.02\%), and Rhodocyclales $(3.42 \%)$, while those in Su were Oceanospirillales (18.69\%), Pseudomonadales (13.19\%), Burkholderiales (10.42\%), Xanthomonadales $(8.88 \%)$, Rhodocyclales $(5.41 \%)$, Sphingomonadales $(5.09 \%)$, and Rhodobacterales $(3.40 \%)$. 


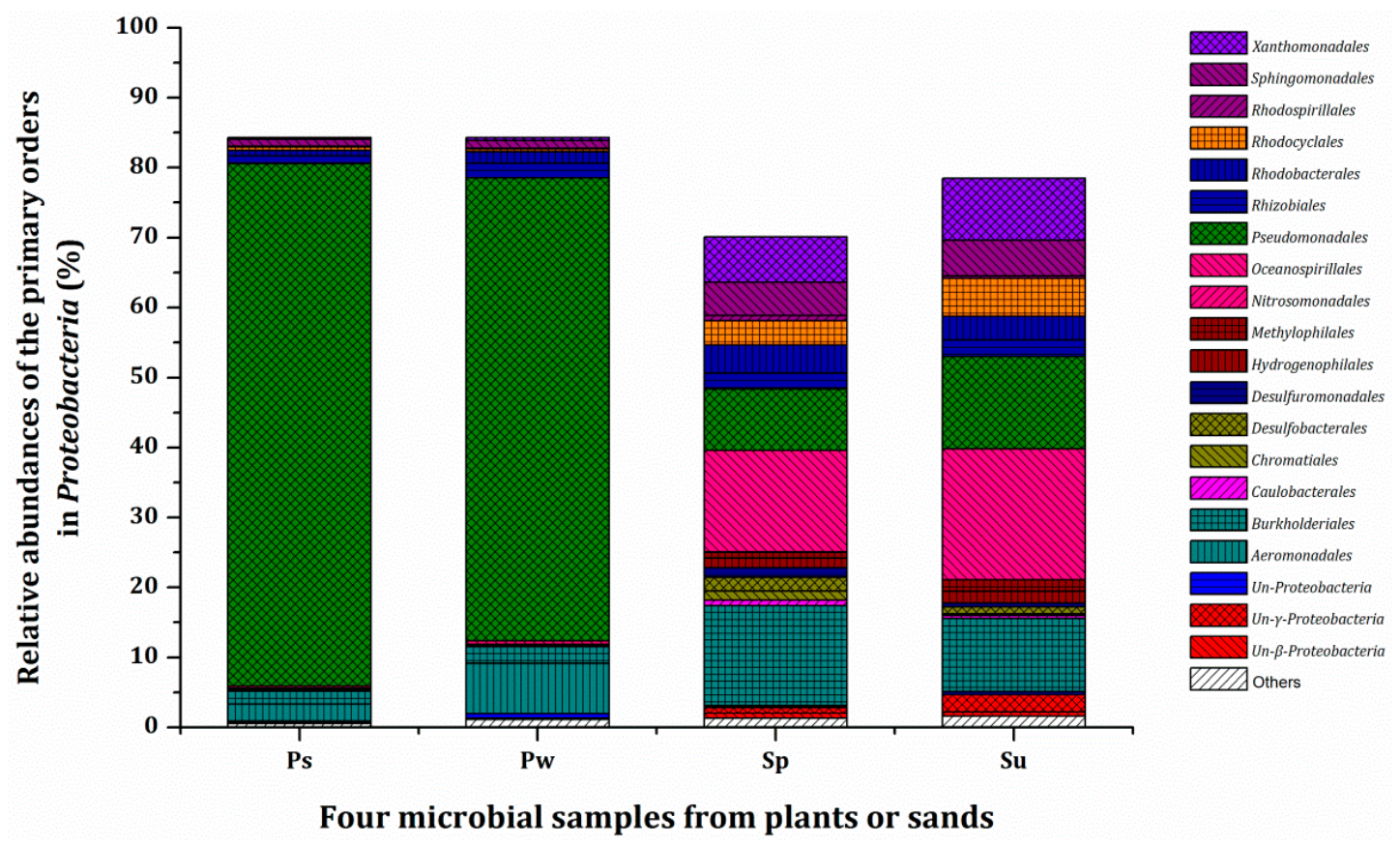

Figure 4. Relative abundances of the primary orders in Proteobacteria in the samples from plants or sands. Orders whose relative abundance is less than $0.5 \%$ (except for Nitrosomonadales) are grouped into "others". Ps: sample from rhizoplane in Tcw; Pw: sample from rhizoplane in Tcp; Sp: sample from sand in Tcw; Su: sample from sand in Tcs. The microbial samples from the plants rhizoplane and the substrate were obtained at the end of the 6th batch.

The primary genera (relative abundance $>1.00 \%$ ) in the four systems with the addition of two nitrifying bacteria (unclassified-Nitrosomonadaceae and Nitrospira), comprised a total of 48 genera (Table A4). According to the list of genera provided by Heylen et al. [40] and Philippot et al. [41], which included at least one denitrifying strain, nearly half of these were closely related to denitrification. Comparison of the community composition of these denitrifying bacteria showed a significant difference among the two groups of wastewater treatment systems. In Ps, Pseudomonas, with a relative abundance of $74.33 \%$, was the dominant genus, followed by Exiguobacterium (8.89\%), Aeromonas (2.44\%), Bacillus (1.72\%), and Rhizobium (0.60\%). In Pw, Pseudomonas accounted for $65.76 \%$, followed by Aeromonas (7.23\%), Exiguobacterium (5.14\%), Paenibacillus (2.93\%), Rhizobium (1.01\%), Acidovorax (0.94\%), Flavobacterium $(0.67 \%)$, and unclassified-Rhodobacteraceae $(0.61 \%)$. The order for Sp was Halomonas (14.49\%), Rhodoferax (7.73\%), Pseudomonas (5.19\%), Arenimonas (5.00\%), unclassified-Bacteroidetes $(4.18 \%)$, Flavobacterium (2.79\%), Perlucidibaca (2.46\%), unclassified-Rhodobacteraceae $(2.20 \%)$, Simplicispira (1.93\%), Hydrogenophaga (1.82\%), and Thiobacillus (1.35\%). The order for Su was Halomonas (18.68\%), Pseudomonas (9.64\%), Arenimonas (5.01\%), Rhodoferax (3.19\%), unclassified-Xanthomonadaceae (3.16\%), Perlucidibaca (2.93\%), Hydrogenophaga (2.79\%), unclassified-Bacteroidetes (1.88\%), unclassified-Rhodobacteraceae (1.84\%), and Thiobacillus (1.71\%). In addition, more abundant nitrifying bacteria were observed in Sp in comparison to $\mathrm{Su}$. The relative abundance of unclassified-Nitrosomonadaceae was recorded as $0.0889 \%$ and $0.0333 \%$ in $\mathrm{Sp}$ and $\mathrm{Su}$, respectively.

\section{Discussion}

Although the process of nitrogen transformation and removal in CWs is complex and attributed to various mechanisms including ammonification, nitrification-denitrification, anammox, vegetation uptake, biomass assimilation, dissimilatory nitrate reduction, substrate adsorption, and ammonia volatilization $[10,42,43]$, it has been widely considered that the removal of nitrogen is primarily due to microbial metabolic pathways [44,45]. Therefore, in the current research, only the nitrogen content was measured in the wastewater as well as the macrophytes. As previously reported, the present results 
indicate that the vegetation uptake pathway in planted systems was limited. It was attributed to the weak growth of $O$. javanica at a low average temperature below $5{ }^{\circ} \mathrm{C}$.

Due to the presence of diverse forms of nitrogen in wastewater, nitrogen removal in CWs often involves a series of microbial communities with a variety of metabolic functions. In general, the removal of nitrogen from wastewater is closely related to the microbial abundance and community composition which directly decides the functional characteristics of microorganisms in the CWs [46,47]. In this study, the presence of macrophytes significantly improved microbial abundances, as well as had slight lifting effects on the richness, diversity, and evenness of microbial composition, which, in turn, led to an enhanced performance of nitrogen removal. This is consistent with previous studies that reported enhanced density, activity, and diversity of microorganisms in the plant rhizosphere [48-51]. Quantitative analysis showed dramatically higher abundances of bacteria and archaea in the plant rhizoplane compared to those in the substrate of both planted and unplanted systems which suggests that it could be potentially attributed to the enlargement and complexity in attachment surface for microbial growth [10].

Nitrification includes two steps [10]. In the first step, ammonia oxidation oxidizes ammonium to nitrite, which is generally believed to be the rate-limiting step of nitrification and is usually marked by the amoA gene [44]. The second step, nitrite oxidation, converts nitrite into nitrate, which involves nitrite-oxidizing bacteria. The organisms that participate in ammonia oxidation mainly belong to two groups. One is ammonia-oxidizing bacteria (AOB), which have long been considered critical in nitrification, and the other is ammonia oxidizing archaea (AOA), which play an active role in nitrification by molecular biological methods. In the current study, archaeal abundances were significantly high when compared to the bacterial abundances in the planted systems. This result was consistent with several previous reports that found that AOA was the preponderant ammonia-oxidizing microorganism in the plant rhizosphere and had significantly active involvement in nitrification in the rhizosphere due to their better adaptability to the rhizosphere microenvironment in comparison to AOB [52-54]). Moreover, the abundances of archaea and amoA gene in the planted systems showed significant increases than those in the unplanted ones. The analysis of bacterial composition at different taxonomic levels also revealed a higher relative abundance of Nitrosomonadaceae, identified as a representative family of $\mathrm{AOB}$, in planted systems compared to the unplanted ones. The results indicate that the presence of macrophytes facilitated nitrogen removal from wastewater via stimulating the abundance of ammonia-oxidizing microorganisms in the FWS-CWS. The detailed mechanism may involve the release of oxygen by roots of macrophytes which changed the partial oxidation-reduction conditions in the rhizosphere. According to the studies applying stoichiometry method, the lowest critical concentration of DO for ammonium oxidation is $1.0 \mathrm{mg} \cdot \mathrm{L}^{-1}$ and the complete nitrification of $1.0 \mathrm{~g}$ ammonia nitrogen needs $4.6 \mathrm{~g}$ of oxygen [5]. Although there is a thin aerobic layer at the water surface due to passive diffusion from air to water, the FWS-CWS is largely an anoxic system because DO decreases with water depth and organic sedimentation at the surface of the substrate consumes a mass of oxygen [5]. Therefore, together with the low temperature, the removal of ammonia nitrogen and TN in the unplanted systems were found to be limited in the current research. In contrast, the removal of ammonia nitrogen in planted systems presented evident superiority in contrast to unplanted ones because wetland macrophytes can efficiently transfer oxygen from air to the CW system via ROL [4]. However, the advantage of TN removal was not recorded in the planted systems during the experiment. This result may be related to the limited nitrate-nitrogen removal which could be attributed to another group of the microbial community named denitrifies.

Denitrifying microorganisms exist across a wide range of microbial groups, which involve Actinomycetes, Aquifaceae, Bacteroides, Firmicutes, Proteobacteria, and even archaea as well as fungus [41]. A total of more than 60 genera have been identified as denitrifying bacteria and most of them belong to Alphaproteobacteria, Betaproteobacteria, and Gammaproteobacteria [41]. In this study, denitrifying bacteria accounted for half of the primary genera listed, which indicated the diversity of denitrifier in the FWS-CWS. Halomonas, Rhodoferax, Pseudomonas, and Arenimonas constituted the four primary genera of 
denitrifying bacteria in both the planted and unplanted systems. Hence, it is likely that the difference in community composition of denitrifying bacteria was not the material cause of the difference in nitrogen removal efficiency between the planted and unplanted systems. In contrast, significant differences between the planted and unplanted systems were obviously revealed by the quantitative analysis of the critical functional genes, including nosZ, nirS, and nirK.

Denitrification, which converts nitrate to nitrogen gas, consists of four steps and commonly occurs under anaerobic conditions [6,55]. The first step which involves converting nitrate into nitrite may occur under aerobic conditions catalyzed by Nap or anaerobic conditions catalyzed by Nar. The second step which converts nitrite into nitric oxide is catalyzed by two key enzymes: dissimilatory copper-containing nitrite reductase encoded by the nirK gene and dissimilatory cd1-containing nitrite reductase encoded by the nirS gene. The third step is the conversion from nitric oxide to nitrous oxide. The last step is catalyzed by the product of the nosZ gene which converts nitrous oxide into nitrogen gas. Additionally, the nos $Z$ gene is often regarded as the marker of complete denitrification while the nirS and nirK genes usually act as the markers for the second denitrification step [6,55]. In the current research, the absolute abundances of the three genes, especially the nos $Z$ gene, presented significant increases in the planted systems in contrast to the unplanted ones. This result indicates the remarkable facilitation of the quantity of denitrifying bacteria by wetland macrophytes which could be ascribed to the increased supply of biodegradable carbon. It is widely believed that the denitrification in CWs depends on organic carbon levels. Ye and Li [56] concluded that the entire denitrification of $1.0 \mathrm{~g}$ nitrate nitrogen into nitrogen gas needed $2.86 \mathrm{~g}$ BOD. Meanwhile, a variety of studies have shown that macrophytes can effectively enhance the carbon content, thus, aiding nitrogen removal in the CWs $[7,25,57]$. On the one hand, plant root exudates can provide available organic compounds to heterotrophic bacteria [8], on the other, plant litter can release various dissolved organic matters including sugars, amino acids, and volatile fatty acids [48,58]. In this study, the enhanced COD content and COD/N ratios in wastewater accompanied by the increased removal of TN from the wastewater were recorded in the planted systems. Despite the optimal COD/N ratio of 5:1 for nearly complete removal of nitrogen in the FWS-CWS [59], the elevated COD/N ratio, which reached up to 2:1 in several later batches in the planted systems, may effectively promote the accumulation of denitrifying microorganisms and stimulate denitrification, and subsequently, comprehensively improve the removal efficiency of TN from wastewater.

Besides the nitrification-denitrification process, anammox has been widely indicated as a new ammonium oxidation process which occurs under anaerobic conditions. Compared with the nitrification-denitrification pathway, the anammox pathway has the advantage of a lower demand for carbon sources $[5,10,55]$. The microorganisms involved in the anammox process have been identified to belong to the order Brocadiales of the phylum Planctomycetes [60,61]. However, no Brocadiales were detected by the analysis based on V3-V4 regions of the 16S rRNA gene in the current research. Nevertheless, the quantitative analysis of the anammox bacterial 16S rRNA gene, which is usually regarded as the marker of anammox process, clearly indicated the presence of anammox bacteria [55]. However, the absolute abundance of anammox bacteria was far lower than that of the amoA gene, which indicated that the ammonia process was not the dominant pathway of the ammonia nitrogen removal. This result was consistent with the opinion that nitrification-denitrification primarily contributes to the removal of ammonia nitrogen when the $\mathrm{C} / \mathrm{N}$ ratio is less than or equal to $6: 1$ in the $\mathrm{CWs}$ [55].

Analysis of bacterial community composition revealed that Proteobacteria was the dominant phylum followed by Bacteroidetes in not only the plant rhizoplane, but also the rhizosphere in the current system. Proteobacteria has been widely considered an active participant in nitrogen removal in the CWs for its high diversity of metabolism which involves global carbon, nitrogen, and sulfur cycling [62]. The results of this study were consistent with several previous studies that indicated Proteobacteria as the dominant bacterial community in a variety of wetland substrates $[48,49,62,63]$. Further comparison of Proteobacteria by order also indicated a difference in the relative abundances of many orders, such as Burkholderiales, Oceanospirillales, Pseudomonadales, and Rhodocyclales, between samples 
from the substrate of planted systems and those from the unplanted ones. All the four mentioned orders have been reported to have a close relationship with denitrification, which indicates different characteristics of nitrogen removal between the planted and unplanted systems [41,64]. Moreover, a higher relative abundance of Bacteroidetes, which was presented by the genera Flavobacterium in the class Flavobacteria, in the planted systems may also relate to the nitrogen removal via the denitrification process [64]. In summary, the enhanced community diversity and evenness of the bacteria, especially denitrifying bacteria, in the planted systems, may play a significant role in the improved removal rate of TN from wastewater.

\section{Conclusions}

In conclusion, the presence of $O$. javanica had a significant facilitating effect on the nitrogen, especially TN, removal from wastewater in the FWS-CWS during the low-temperature season with mean water temperature lower than $10{ }^{\circ} \mathrm{C}$. Because the macrophyte could provide extra organic carbon by root exudation and plant residues, it enhanced the microbial abundance, diversity, and evenness, as well as the abundances of amoA, nosZ, nirS, and nirK, and those closely related to nitrification-denitrification, on the rhizoplane and in the substrate. This suggests that FWS-CWS planted with $O$. javanica is a reliable option for a higher removal rate of nitrogen during low-temperature seasons. However, the increased COD concentration in planted systems may also cause secondary pollution and pose a new challenge for the wastewater purification, especially, when the wetland macrophytes begin to shrivel and die under low temperatures. Therefore, further studies on the selection of plant species, the control of plant density, as well as feasible improvements to the approach, for instance, adopting the FWS-CWS as part of an integrated wastewater treatment train, merit more attention in the future.

Author Contributions: S.S. and P.W. conceived, designed, and performed the experiments; Y.L. performed some experiments; D.Z. and X.L. guided the experiments and the writings; S.A. gave suggestions and guidance.

Funding: This research was financially supported by the Major Science and Technology Program for Water Pollution Control and Treatment (No. 2017ZX07602002).

Acknowledgments: We would like to thank Genergy Biotechnology Limited Corporation (Shanghai, China) for the 16S rRNA gene real-time quantitative PCR analysis and Illumina Miseq analysis.

Conflicts of Interest: The authors declare that they have no conflict of interest.

\section{Appendix A}

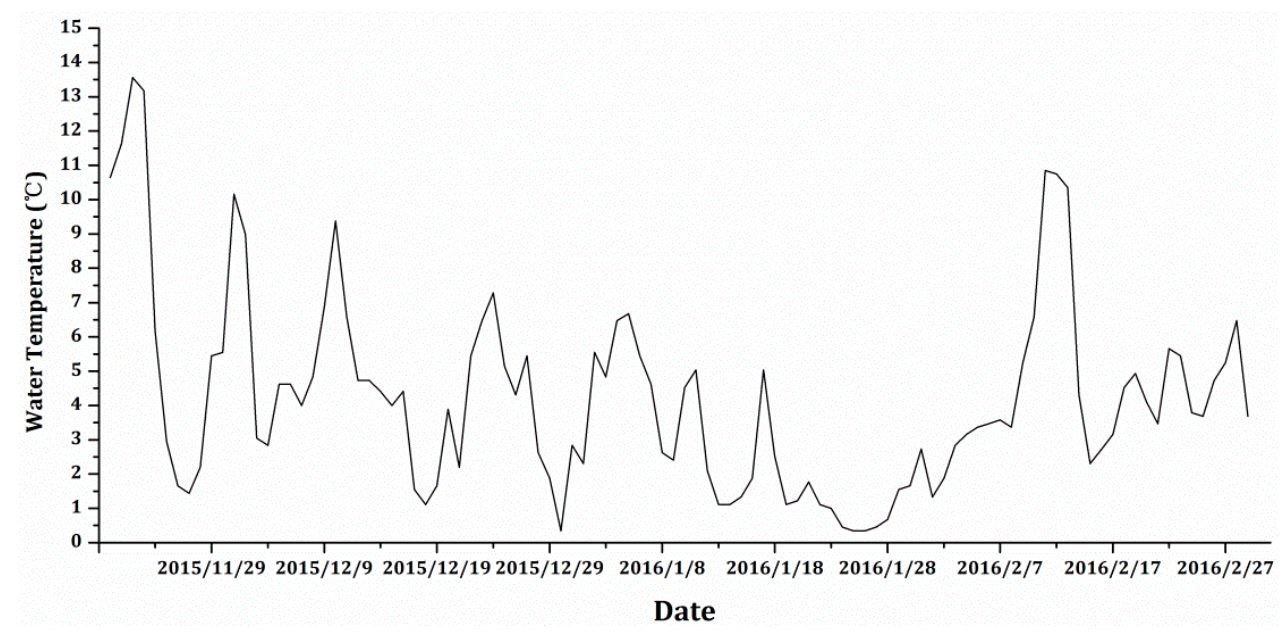

Figure A1. Daily water temperature of the systems during the pre-processing and experimental periods. 
Table A1. Primers of QPCR.

\begin{tabular}{|c|c|c|}
\hline Target & Primer & Primer Sequence $\left(5^{\prime}-3^{\prime}\right)$ \\
\hline \multirow{2}{*}{ bacterial 16S rRNA gene } & 690F & TGTGTAGCGGTGAAATGCG \\
\hline & $829 \mathrm{R}$ & CATCGTTTACGGCGTGGAC \\
\hline \multirow{2}{*}{ archaeal 16S rRNA gene } & ARC344F & ACGGGGYGCAGCAGGCGCGA \\
\hline & ARC915R & GTGCTCCCCCGCCAATTCCT \\
\hline \multirow{2}{*}{ ANO 16S rRNA gene } & AMX809F & GCCGTAAACGATGGGCACT \\
\hline & AMX1066R & AACGTCTCACGACACGAGCTG ${ }^{[6 /]}$ \\
\hline \multirow{2}{*}{$a m o A$} & amo1F & GGGGGTTTCTACTGGTGGT \\
\hline & amo2R & ССССTCKGSAAAGCCTTCTTC \\
\hline \multirow{2}{*}{ nos $Z$} & NosZ 1527F & CGCTGTTCHTCGACAGYCA \\
\hline & NosZ 1773R & ATRTCGATCARCTGBTCGTT \\
\hline \multirow{2}{*}{ nirs } & nirS cd3AF & GTSAACGTSAAGGARACSGG \\
\hline & nirs R3cd & GASTTCGGRTGSGTCTTGA \\
\hline \multirow{2}{*}{ nirK } & nirK 583F & TCATGGTGCTGCCGCGKGACGG \\
\hline & nirK 909R & GAACTTGCCGGTKGCCCAGAC ${ }^{\prime}$ \\
\hline
\end{tabular}

Table A2. Detailed information for $16 \mathrm{~S}$ rRNA gene qPCR and Illumina MiSeq sequencing analysis.

\begin{tabular}{|c|c|c|}
\hline Information & qPCR & Illumina MiSeq Sequencing \\
\hline Analysis system & $\begin{array}{l}\text { Illumina-Eco real-time PCR system } \\
\text { (Illumina, San Diego, CA, USA) }\end{array}$ & $\begin{array}{l}\text { Illumina MiSeq } 2500 \text { sequencing platform } \\
\text { (Illumina, San Diego, CA, USA) }\end{array}$ \\
\hline Reaction mixture & $\begin{array}{l}5.0 \mu \mathrm{L} \text { SYBR }{ }^{\circledR} \text { Premix Ex } \text { Taq }^{\mathrm{TM}} \mathrm{II} \\
\text { (Takara, Otsu, Japan), } \\
1.0 \mu \mathrm{L} \text { template DNA (diluted } 100 \text {-fold), } \\
0.5 \mu \mathrm{L} \text { forward and } 0.5 \mu \mathrm{L} \text { reverse } \\
\text { primers }(10 \mu \mathrm{M}) \text {, } \\
\text { 3.0 } \mu \mathrm{L} \text { RNase-free water }\end{array}$ & $\begin{array}{l}25 \mu \mathrm{L} \text { reaction mixture (including } 10 \mathrm{ng} \\
\text { template, } 0.5 \mu \mathrm{L} \text { forward primer, } 0.5 \mu \mathrm{L} \\
\text { reverse primer) }\end{array}$ \\
\hline PCR program & $\begin{array}{l}30 \mathrm{~s} \text { at } 94^{\circ} \mathrm{C}, 40 \text { cycles of } 5 \mathrm{~s} \text { at } 95^{\circ} \mathrm{C} \text {, } \\
30 \mathrm{~s} \text { at } 55^{\circ} \mathrm{C}(\text { amo } A) \text { or } 60^{\circ} \mathrm{C} \text { (other } \\
\text { genes), and } 30 \mathrm{~s} \text { at } 72{ }^{\circ} \mathrm{C}\end{array}$ & $\begin{array}{l}3 \mathrm{~min} \text { at } 94^{\circ} \mathrm{C}, 30 \text { cycles of } 10 \mathrm{~s} \text { at } 94^{\circ} \mathrm{C} \text {, } \\
15 \mathrm{~s} \text { at } 55^{\circ} \mathrm{C} \text {, and } 72{ }^{\circ} \mathrm{C} \text { for } 30 \mathrm{~s} \text {, and a } \\
\text { final incubation at } 72{ }^{\circ} \mathrm{C} \text { for } 7 \mathrm{~min}\end{array}$ \\
\hline PCR product purification & / & $\begin{array}{l}\text { Agencourt AMPure beads (Beckman } \\
\text { Coulter, Inc., Fullerton, CA, USA) }\end{array}$ \\
\hline Libraries construction & / & $\begin{array}{l}\text { NEBNext Ultra DNA Library Prep Kit for } \\
\text { Illumina (New England Biolabs Inc., } \\
\text { Boston, MA, USA) }\end{array}$ \\
\hline
\end{tabular}

Table A3. Alpha diversity analysis at 5\% dissimilarity based on the 16S rRNA gene Miseq sequencing analysis.

\begin{tabular}{cccccc}
\hline Sample & OTUs & ACE & Simpson & Shannon-Even & Coverage \\
\hline $\mathrm{Ps}$ & 446 & 629.398681 & 0.219313 & 0.382270 & 0.994148 \\
\hline $\mathrm{Pw}$ & 567 & 720.449124 & 0.137883 & 0.462411 & 0.994037 \\
\hline $\mathrm{Sp}$ & 710 & 788.302182 & 0.031945 & 0.748674 & 0.995926 \\
\hline $\mathrm{Su}$ & 675 & 761.131090 & 0.046425 & 0.695539 & 0.995444 \\
\hline
\end{tabular}

The richness estimators (ACE), diversity indices (Simpson), evenness indices (Shannon-even), and coverage (Good's coverage index) were calculated using the Mothur program. Ps: sample from rhizoplane in Tcw; Pw: sample from rhizoplane in Tcp; Sp: sample from sand in Tcw; Su: sample from sand in Tcs. The microbial samples from the plants rhizoplane and the substrate were obtained at the end of the 6th batch. 
Table A4. The main genera (relative abundance $>1.00 \%$ ) with the addition of two nitrifying bacteria (Nitrospira and unclassified-Nitrosomonadaceae) in the samples from rhizoplane or sand.

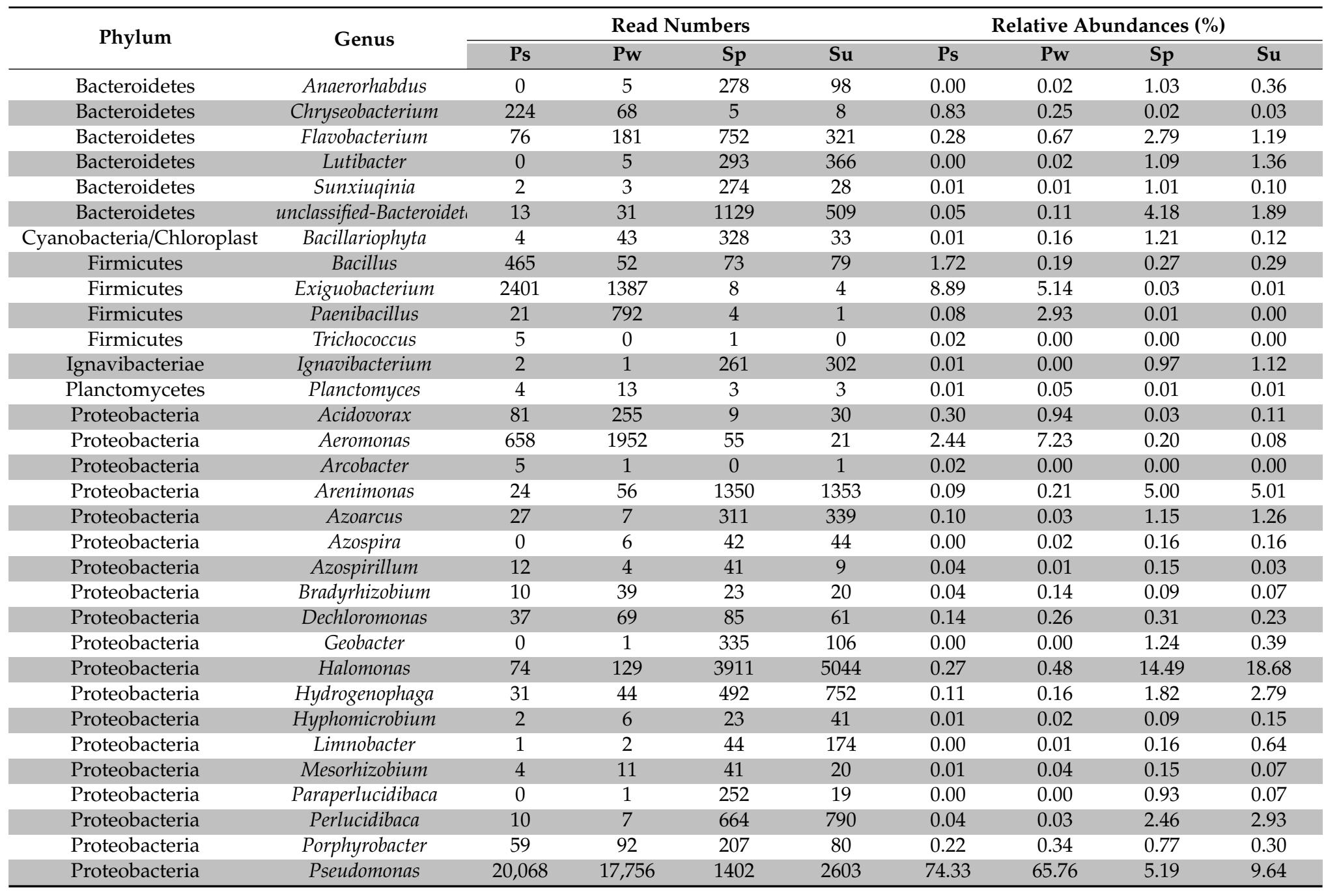


Table A4. Cont.

\begin{tabular}{|c|c|c|c|c|c|c|c|c|c|}
\hline \multirow{2}{*}{ Phylum } & \multirow{2}{*}{ Genus } & \multicolumn{4}{|c|}{ Read Numbers } & \multicolumn{4}{|c|}{ Relative Abundances (\%) } \\
\hline & & Ps & Pw & $\mathrm{Sp}$ & $\mathrm{Su}$ & Ps & Pw & $\mathrm{Sp}$ & $\mathrm{Su}$ \\
\hline Proteobacteria & Pseudoxanthomonas & 1 & 2 & 6 & 6 & 0.00 & 0.01 & 0.02 & 0.02 \\
\hline Proteobacteria & Rhizobium & 163 & 272 & 50 & 48 & 0.60 & 1.01 & 0.19 & 0.18 \\
\hline Proteobacteria & Rhodoferax & 39 & 78 & 2088 & 863 & 0.14 & 0.29 & 7.73 & 3.20 \\
\hline Proteobacteria & Sandaracinobacter & 0 & 0 & 84 & 307 & 0.00 & 0.00 & 0.31 & 1.14 \\
\hline Proteobacteria & Shewanella & 0 & 17 & 5 & 1 & 0.00 & 0.06 & 0.02 & 0.00 \\
\hline Proteobacteria & Sulfuritalea & 1 & 5 & 207 & 644 & 0.00 & 0.02 & 0.77 & 2.39 \\
\hline Proteobacteria & Thauera & 1 & 4 & 94 & 179 & 0.00 & 0.01 & 0.35 & 0.66 \\
\hline Proteobacteria & Thiobacillus & 1 & 0 & 367 & 463 & 0.00 & 0.00 & 1.36 & 1.71 \\
\hline Proteobacteria & unclassified-Rhodobacte & 66 & 165 & 594 & 496 & 0.24 & 0.61 & 2.20 & 1.84 \\
\hline Proteobacteria & unclassified-Sphingomonada & alds & 43 & 202 & 352 & 0.10 & 0.16 & 0.75 & 1.30 \\
\hline Proteobacteria & unclassified-Xanthomor & 8 & 15 & 219 & 855 & 0.03 & 0.06 & 0.81 & 3.17 \\
\hline
\end{tabular}

Possible denitrifying bacteria according to Heylen et al. (2006) and Philippot et al. (2007) in each sample are given in bold. Ps: sample from rhizoplane in Tcw; Pw: sample from rhizoplane in Tcp; Sp: sample from sand in Tcw; Su: sample from sand in Tcs. 


\section{References}

1. Vymazal, J. Constructed wetlands for treatment of industrial wastewaters: A review. Ecol. Eng. 2014, 73, 724-751. [CrossRef]

2. Zhang, D.Q.; Jinadasa, K.; Gersberg, R.M.; Liu, Y.; Ng, W.J.; Tan, S.K. Application of constructed wetlands for wastewater treatment in developing countries-A review of recent developments (2000-2013). J. Environ. Manag. 2014, 141, 116-131. [CrossRef] [PubMed]

3. Chen, H. Surface-Flow Constructed Treatment Wetlands for Pollutant Removal: Applications and Perspectives. Wetlands 2011, 31, 805-814. [CrossRef]

4. Kadlec, R.H.; Wallace, S. Treatment Wetlands, 2nd ed.; CRC Press: Boca Raton, FL, USA, 2009.

5. Faulwetter, J.L.; Gagnon, V.; Sundberg, C.; Chazarenc, F.; Burr, M.D.; Brisson, J.; Camper, A.K.; Stein, O.R. Microbial processes influencing performance of treatment wetlands: A review. Ecol. Eng. 2009, 35, 987-1004. [CrossRef]

6. Saeed, T.; Sun, G. A review on nitrogen and organics removal mechanisms in subsurface flow constructed wetlands: Dependency on environmental parameters, operating conditions and supporting media. J. Environ. Manag. 2012, 112, 429-448. [CrossRef]

7. Fu, G.; Huangshen, L.; Guo, Z.; Zhou, Q.; Wu, Z. Effect of plant-based carbon sources on denitrifying microorganisms in a vertical flow constructed wetland. Bioresour. Technol. 2017, 224, 214-221. [CrossRef]

8. Truu, M.; Juhanson, J.; Truu, J. Microbial biomass, activity and community composition in constructed wetlands. Sci. Total Environ. 2009, 407, 3958-3971. [CrossRef]

9. Vymazal, J. Constructed wetlands for wastewater treatment: Five decades of expericence. Environ. Sci. Technol. 2011, 45, 61-69. [CrossRef] [PubMed]

10. Meng, P.; Pei, H.; Hu, W.; Shao, Y.; Li, Z. How to increase microbial degradation in constructed wetlands: Influencing factors and improvement measures. Bioresour. Technol. 2014, 157, 316-326. [CrossRef]

11. Vymazal, J.; Kröpfelová, L. Removal of organics in constructed wetlands with horizontal sub-surface flow: A review of the field experience. Sci. Total Environ. 2009, 407, 3911-3922. [CrossRef] [PubMed]

12. Rousseau, D.; Horton, D.; Griffin, P.; Vanrolleghem, P.; De Pauw, N. Impact of operational maintenance on the asset life of storm reed beds. Water Sci. Technol. 2005, 51, 243-250. [CrossRef]

13. Faulwetter, J.L.; Burr, M.D.; Parker, A.E.; Stein, O.R.; Camper, A.K. Influence of season and plant species on the abundance and diversity of sulfate reducing bacteria and ammonia oxidizing bacteria in constructed wetland microcosms. Microb. Ecol. 2013, 65, 111-127. [CrossRef] [PubMed]

14. Shelef, O.; Gross, A.; Rachmilevitch, S. Role of Plants in a Constructed Wetland: Current and New Perspectives. Water 2013, 5, 405-419. [CrossRef]

15. Ahn, C.; Gillevet, P.; Sikaroodi, M. Molecular characterization of microbial communities in treatment microcosm wetlands as influenced by macrophytes and phosphorus loading. Ecol. Indic. 2007, 7, 852-863. [CrossRef]

16. Gorra, R.; Coci, M.; Ambrosoli, R.; Laanbroek, H. Effects of substratum on the diversity and stability of ammonia-oxidizing communities in a constructed wetland used for wastewater treatment. J. Appl. Microbiol. 2007, 103, 1442-1452. [CrossRef] [PubMed]

17. DeJournett, T.D.; Arnold, W.A.; LaPara, T.M. The characterization and quantification of methanotrophic bacterial populations in constructed wetland sediments using PCR targeting 16S rRNA gene fragments. Appl. Soil Ecol. 2007, 35, 648-659. [CrossRef]

18. Baptista, J.D.C.; Davenport, R.J.; Donnelly, T.; Curtis, T.P. The microbial diversity of laboratory-scale wetlands appears to be randomly assembled. Water Res. 2008, 42, 3182-3190. [CrossRef] [PubMed]

19. Brisson, J.; Chazarenc, F. Maximizing pollutant removal in constructed wetlands: Should we pay more attention to macrophyte species selection? Sci. Total Environ. 2009, 407, 3923-3930. [CrossRef] [PubMed]

20. Cardinal, P.; Anderson, J.C.; Carlson, J.C.; Low, J.E.; Challis, J.K.; Beattie, S.A.; Bartel, C.N.; Elliott, A.D.; Montero, O.F.; Lokesh, S.; et al. Macrophytes may not contribute significantly to removal of nutrients, pharmaceuticals, and antibiotic resistance in model surface constructed wetlands. Sci. Total Environ. 2014, 482, 294-304. [CrossRef] [PubMed]

21. Yan, Y.; Xu, J. Improving Winter Performance of Constructed Wetlands for Wastewater Treatment in Northern China: A Review. Wetlands 2013, 34, 243-253. [CrossRef] 
22. Gao, J.; Wang, W.; Guo, X.; Zhu, S.; Chen, S.; Zhang, R. Nutrient removal capability and growth characteristics of Iris sibirica in subsurface vertical flow constructed wetlands in winter. Ecol. Eng. 2014, 70, 351-361. [CrossRef]

23. Zou, X.; Zhang, H.; Zuo, J.; Wang, P.; Zhao, D.; An, S. Decreasing but still significant facilitation effect of cold-season macrophytes on wetlands purification function during cold winter. Sci. Rep. 2016, 6, 27011. [CrossRef] [PubMed]

24. Vymazal, J. Emergent plants used in free water surface constructed wetlands: A review. Ecol. Eng. 2013, 61, 582-592. [CrossRef]

25. Hang, Q.; Wang, H.; Chu, Z.; Ye, B.; Li, C.; Hou, Z. Application of plant carbon source for denitrification by constructed wetland and bioreactor: Review of recent development. Environ. Sci. Pollut. Res. 2016, 23, 8260-8274. [CrossRef]

26. Zhou, X.; Wang, G. Nutrient concentration variations during Oenanthe javanica growth and decay in the ecological floating bed system. J. Environ. Sci. 2010, 22, 1710-1717. [CrossRef]

27. Chen, Z.; Cuervo, D.P.; Müller, J.A.; Wiessner, A.; Köser, H.; Vymazal, J.; Kästner, M.; Kuschk, P. Hydroponic root mats for wastewater treatment-A review. Environ. Sci. Pollut. Res. 2016, 23, 15911-15928. [CrossRef]

28. Rice, E.; Baird, R.; Eaton, A.; Clesceri, L. Standard Methods for the Examination of Water and Waste Water; American Public Health Association: Washington, DC, USA, 2012.

29. Li, H.S.; Sun, Q.; Zhao, S.J.; Zhang, W.H. Principles and Techniques of Pant Physiological Biochemical Experiment; Higher Education Press: Beiijng, China, 2000.

30. Toet, S.; Bouwman, M.; Cevaal, A.; Verhoeven, J.T.A. Nutrient removal through autumn harvest ofphragmites australisandthypha latifoliashoots in relation to nutrient loading in a wetland system used for polishing sewage treatment plant effluent. Environ. Lett. 2005, 40, 1133-1156. [CrossRef]

31. Kludze, H.K.; Delaune, R.D.; Patrick, W.H. A Colorimetric Method for Assaying Dissolved Oxygen Loss from Container-Grown Rice Roots. Agron. J. 1994, 86, 483-487. [CrossRef]

32. Wu, C.; Shu, W.; Zhu, Y.-G.; Ye, Z.; Wong, M. Arsenic accumulation and speciation in rice are affected by root aeration and variation of genotypes. J. Exp. Bot. 2011, 62, 2889-2898. [CrossRef] [PubMed]

33. Edwards, J.; Johnson, C.; Santos-Medellín, C.; Lurie, E.; Podishetty, N.K.; Bhatnagar, S.; Eisen, J.A.; Sundaresan, V. Structure, variation, and assembly of the root-associated microbiomes of rice. Proc. Natl. Acad. Sci. USA 2015, 112, E911-E920. [CrossRef] [PubMed]

34. Chen, Y.; Wen, Y.; Zhou, Q.; Vymazal, J. Effects of plant biomass on denitrifying genes in subsurface-flow constructed wetlands. Bioresour. Technol. 2014, 157, 341-345. [CrossRef] [PubMed]

35. Schloss, P.D.; Westcott, S.L.; Ryabin, T.; Hall, J.R.; Hartmann, M.; Hollister, E.B.; Lesniewski, R.A.; Oakley, B.B.; Parks, D.H.; Robinson, C.J.; et al. Introducing mothur: Open-Source, Platform-Independent, Community-Supported Software for Describing and Comparing Microbial Communities. Appl. Environ. Microbiol. 2009, 75, 7537-7541. [CrossRef] [PubMed]

36. Wang, Q.; Garrity, G.M.; Tiedje, J.M.; Cole, J.R. Naïve Bayesian Classifier for Rapid Assignment of rRNA Sequences into the New Bacterial Taxonomy. Appl. Environ. Microbiol. 2007, 73, 5261-5267. [CrossRef]

37. Chao, A. Nonparametric estimation of the number of classes in a population. Scand. J. Stat. 1984, 11, $265-270$.

38. Hill, M.O. Diversity and Evenness: A Unifying Notation and Its Consequences. Ecology 1973, 54, 427-432. [CrossRef]

39. Peet, R.K. The Measurement of Species Diversity. Annu. Rev. Ecol. Syst. 1974, 5, 285-307. [CrossRef]

40. Heylen, K.; Vanparys, B.; Wittebolle, L.; Verstraete, W.; Boon, N.; De Vos, P. Cultivation of Denitrifying Bacteria: Optimization of Isolation Conditions and Diversity Study. Appl. Environ. Microbiol. 2006, 72, 2637-2643. [CrossRef]

41. Philippot, L.; Hallin, S.; Schloter, M. Ecology of Denitrifying Prokaryotes in Agricultural Soil. Adv. Agron. 2007, 96, 249-305.

42. Wu, S.; Kuschk, P.; Brix, H.; Vymazal, J.; Dong, R. Development of constructed wetlands in performance intensifications for wastewater treatment: A nitrogen and organic matter targeted review. Water Res. 2014, 57, 40-55. [CrossRef] [PubMed]

43. Wu, S.; Wallace, S.; Brix, H.; Kuschk, P.; Kirui, W.K.; Masi, F.; Dong, R. Treatment of industrial effluents in constructed wetlands: Challenges, operational strategies and overall performance. Environ. Pollut. 2015, 201, 107-120. [CrossRef] [PubMed] 
44. Li, L.; He, C.; Ji, G.; Zhi, W.; Sheng, L. Nitrogen removal pathways in a tidal flow constructed wetland under flooded time constraints. Ecol. Eng. 2015, 81, 266-271. [CrossRef]

45. Cui, L.; Ouyang, Y.; Gu, W.; Yang, W.; Xu, Q. Evaluation of nutrient removal efficiency and microbial enzyme activity in a baffled subsurface-flow constructed wetland system. Bioresour. Technol. 2013, 146, 656-662. [CrossRef] [PubMed]

46. Zhong, F.; Wu, J.; Dai, Y.; Yang, L.; Zhang, Z.; Cheng, S.; Zhang, Q. Bacterial community analysis by pcr-dgge and 454-pyrosequencing of horizontal subsurface flow constructed wetlands with front aeration. Appl. Microbiol. Biotechnol. 2015, 99, 1499-1512. [CrossRef]

47. Saunders, A.M.; Larsen, P.; Nielsen, P.H. Comparison of nutrient-removing microbial communities in activated sludge from full-scale MBRs and conventional plants. Water Sci. Technol. 2013, 68, 366-371. [CrossRef]

48. Chen, Y.; Wen, Y.; Tang, Z.; Huang, J.; Zhou, Q.; Vymazal, J. Effects of plant biomass on bacterial community structure in constructed wetlands used for tertiary wastewater treatment. Ecol. Eng. 2015, 84, 38-45. [CrossRef]

49. Wang, Q.; Xie, H.; Ngo, H.H.; Guo, W.; Zhang, J.; Liu, C.; Liang, S.; Hu, Z.; Yang, Z.; Zhao, C. Microbial abundance and community in subsurface flow constructed wetland microcosms: Role of plant presence. Environ. Sci. Pollut. Res. Int. 2016, 23, 4036-4045. [CrossRef] [PubMed]

50. Salvato, M.; Borin, M.; Doni, S.; Macci, C.; Ceccanti, B.; Marinari, S.; Masciandaro, G. Wetland plants, micro-organisms and enzymatic activities interrelations in treating $\mathrm{N}$ polluted water. Ecol. Eng. 2012, 47, 36-43. [CrossRef]

51. Menon, R.; Jackson, C.R.; Holland, M.M. The Influence of Vegetation on Microbial Enzyme Activity and Bacterial Community Structure in Freshwater Constructed Wetland Sediments. Wetlands 2013, 33, 365-378. [CrossRef]

52. Sollai, M.; Hopmans, E.C.; Schouten, S.; Keil, R.G.; Damste, J.S.S. Intact polar lipids of Thaumarchaeota and anammox bacteria as indicators of N-cycling in the Eastern Tropical North Pacific oxygen deficient zone. Biogeosci. Discuss. 2015, 12, 4833-4864. [CrossRef]

53. Paranychianakis, N.V.; Tsiknia, M.; Kalogerakis, N. Pathways regulating the removal of nitrogen in planted and unplanted subsurface flow constructed wetlands. Water Res. 2016, 102, 321-329. [CrossRef] [PubMed]

54. Berg, C.; Vandieken, V.; Thamdrup, B.; Jurgens, K. Significance of archaeal nitrification in hypoxic waters of the baltic sea. ISME J. 2015, 9, 1319-1332. [CrossRef]

55. Zhi, W.; Ji, G. Quantitative response relationships between nitrogen transformation rates and nitrogen functional genes in a tidal flow constructed wetland under C/N ratio constraints. Water Res. 2014, 64, 32-41. [CrossRef]

56. Ye, F.; Li, Y. Enhancement of nitrogen removal in towery hybrid constructed wetland to treat domestic wastewater for small rural communities. Ecol. Eng. 2009, 35, 1043-1050. [CrossRef]

57. Wang, W.; Ding, Y.; Ullman, J.L.; Ambrose, R.F.; Song, X.; Zhao, Z. Nitrogen removal performance in planted and unplanted horizontal subsurface flow constructed wetlands treating different influent COD/N ratios. Environ. Sci. Pollut. Res. 2016, 23, 9012-9018. [CrossRef] [PubMed]

58. Vymazal, J. Removal of nutrients in various types of constructed wetlands. Sci. Total Environ. 2007, 380, 48-65. [CrossRef]

59. Wu, J.; Zhang, J.; Jia, W.; Xie, H.; Gu, R.R.; Li, C.; Gao, B. Impact of COD/N ratio on nitrous oxide emission from microcosm wetlands and their performance in removing nitrogen from wastewater. Bioresour. Technol. 2009, 100, 2910-2917. [CrossRef] [PubMed]

60. Zhu, G.; Jetten, M.S.M.; Kuschk, P.; Ettwig, K.F.; Yin, C. Potential roles of anaerobic ammonium and methane oxidation in the nitrogen cycle of wetland ecosystems. Appl. Microbiol. Biotechnol. 2010, 86, 1043-1055. [CrossRef] [PubMed]

61. Jetten, M.S.; Kuenen, G.; Wagner, M.; Fuerst, J.; Van Loosdrecht, M.; Strous, M. Microbiology and application of the anaerobic ammonium oxidation ('anammox') process. Curr. Opin. Biotechnol. 2001, 12, 283-288. [CrossRef]

62. Ansola, G.; Arroyo, P.; De Miera, L.E.S. Characterisation of the soil bacterial community structure and composition of natural and constructed wetlands. Sci. Total Environ. 2014, 473, 63-71. [CrossRef] [PubMed] 
63. Zhang, J.; Wang, Q.; Fan, J.; Xie, H.; Liu, C.; Liang, S.; Hu, Z.; Yang, Z.; Zhao, C. Comparisons of microbial abundance and community among different plant species in constructed wetlands in summer. Ecol. Eng. 2015, 82, 376-380. [CrossRef]

64. Lv, X.; Yu, J.; Fu, Y.; Ma, B.; Qu, F.; Ning, K.; Wu, H. A Meta-Analysis of the Bacterial and Archaeal Diversity Observed in Wetland Soils. Sci. J. 2014, 2014, 1-12. [CrossRef]

65. Liu, S.; Ying, G.-G.; Liu, Y.-S.; Peng, F.-Q.; He, L.-Y. Degradation of Norgestrel by Bacteria from Activated Sludge: Comparison to Progesterone. Environ. Sci. Technol. 2013, 47, 10266-10276. [CrossRef]

66. Nakaya, A.; Onodera, Y.; Nakagawa, T.; Satoh, K.; Takahashi, R.; Sasaki, S.; Tokuyama, T. Analysis of Ammonia Monooxygenase and Archaeal 16S rRNA Gene Fragments in Nitrifying Acid-Sulfate Soil Microcosms. Microbes Environ. 2009, 24, 168-174. [CrossRef]

67. Tsushima, I.; Kindaichi, T.; Okabe, S. Quantification of anaerobic ammonium-oxidizing bacteria in enrichment cultures by real-time PCR. Water Res. 2007, 41, 785-794. [CrossRef] [PubMed]

68. Okano, Y.; Hristova, K.R.; Leutenegger, C.M.; Jackson, L.E.; Denison, R.F.; Gebreyesus, B.; Lebauer, D.; Scow, K.M. Application of Real-Time PCR to Study Effects of Ammonium on Population Size of Ammonia-Oxidizing Bacteria in Soil. Appl. Environ. Microbiol. 2004, 70, 1008-1016. [CrossRef] [PubMed]

69. Scala, D.J.; Kerkhof, L.J. Nitrous oxide reductase (nosz) gene-specific pcr primers for detection of denitrifiers and three nosz genes from marine sediments. FEMS Microbiol. Lett. 1998, 162, 61-68. [CrossRef]

70. Throback, I.N.; Enwall, K.; Jarvis, A.; Hallin, S. Reassessing pcr primers targeting nirs, nirk and nosz genes for community surveys of denitrifying bacteria with dgge. FEMS Microbiol. Ecol. 2004, 49, 401-417. [CrossRef]

71. Yan, T.; Zu, Y.; Fields, M.W.; Tiedje, J.M.; Wu, L.; Zhou, J. Molecular diversity and characterization of nitrite reductase gene fragments (nirk and nirs) from nitrate- and uranium-contaminated groundwater. Environ. Microbiol. 2003, 5, 13-24. [CrossRef]

(C) 2019 by the authors. Licensee MDPI, Basel, Switzerland. This article is an open access article distributed under the terms and conditions of the Creative Commons Attribution (CC BY) license (http://creativecommons.org/licenses/by/4.0/). 